\title{
Correction to: The ratio of shear to elastic modulus of in- plane loaded masonry
}

\author{
Bastian Valentin Wilding - Michele Godio - Katrin Beyer
}

Published online: 16 March 2021

(C) The Author(s) 2021

\section{Correction to:}

Materials and Structures (2020) 53:40 https://doi.org/10.1617/s11527-020-01464-1

The article "The ratio of shear to elastic modulus of inplane loaded masonry", written by Bastian Valentin Wilding, Michele Godio and Katrin Beyer, was originally published electronically on the publisher's internet portal on 15 April 2020 without open access. The copyright of the article changed in February 2021 to (C) The Author(s) 2021 and the article is forthwith distributed under the terms of the Creative Commons Attribution 4.0 International License (https:// creativecommons.org/licenses/by/4.0/), which permits use, duplication, adaptation, distribution and reproduction in any medium or format, as long as you give appropriate credit to the original author(s) and the

The original article can be found online at https:// doi.org/10.1617/s11527-020-01464-1.

B. V. Wilding · M. Godio · K. Beyer ( $\square)$

Laboratory of Earthquake Engineering and Structural Dynamics (EESD), School of Architecture, Civil and Environmental Engineering (ENAC), Écolecole Polytechnique Fédérale de Lausanne (EPFL), EPFL ENAC IIC EESD, GC B2 495, Station 18, 1015 Lausanne,

Switzerland

e-mail: katrin.beyer@epfl.ch source, provide a link to the Creative Commons license and indicate if changes were made.

Open Access This article is licensed under a Creative Commons Attribution 4.0 International License, which permits use, sharing, adaptation, distribution and reproduction in any medium or format, as long as you give appropriate credit to the original author(s) and the source, provide a link to the Creative Commons licence, and indicate if changes were made. The images or other third party material in this article are included in the article's Creative Commons licence, unless indicated otherwise in a credit line to the material. If material is not included in the article's Creative Commons licence and your intended use is not permitted by statutory regulation or exceeds the permitted use, you will need to obtain permission directly from the copyright holder. To view a copy of this licence, visit http://creativecommons.org/licenses/by/4.0/.

Publisher's Note Springer Nature remains neutral with regard to jurisdictional claims in published maps and institutional affiliations. 